\title{
PRA-DESAIN WISATA HIJAU SEMPADAN SUNGAI DAN COMMUNITY CENTER KAMPUNG LENGKONG KYAI, TANGERANG - BANTEN
}

\author{
Muhammar Khamdevi ${ }^{*}$, Andrey Caesar Effendi ${ }^{2}$, Moses Lo ${ }^{3}$, Muhammad Gerry \\ Malik Prahasta ${ }^{4}$, Nur Hakim Rusli ${ }^{5}$, Leon Liauwnardy ${ }^{6}$ \\ 1,2,3,4,5,6Universitas Matana, Tangerang, Banten, Indonesia \\ *Penulis Koresponsensi, email: m.khamdevi@gmail.com
}

Received:15/10/2021

Revised:18/10/2021

Accepted:20/10/2021

\begin{abstract}
Lengkong Kyai Village is a Historical Heritage Village in Tangerang Regency. The existence of this village is increasingly surrounded and isolated by the development of modern formal housing in BSD City, so that its physical condition is increasingly became slum and its identity as a historical heritage village is decreasing. The Tangerang Regency Government has directed this village as a Pilgrimage Tourism Village, but has not yet had a thorough plan. Therefore, the KKL and PKM activities of the Architecture Study Program tried to plan a design that was focused on the Cisadane River side of this village, because this side is where the village is easily recognizable from the main road of $B S D$ City. This activity resulted in a pre-design of green tourism and a community center on the river border that was connected to historical heritage objects in the village so that it became a unified program of spiritual or religious tourism activities.
\end{abstract}

Keywords: lengkong kyai, community center, heritage, tourism arechitecture

\begin{abstract}
Abstrak. Kampung Lengkong Kyai adalah Kampung Pusaka Bersejarah di Kabupaten Tangerang. Keberadaan kampung ini semakin terkepung dan terisolasi oleh pengembangan perumahan-perumahan formal modern BSD City, sehingga kondisi fisiknya semakin kumuh dan identitasnya sebagai kampung pusaka bersejarah semakin menurun. Pemerintah Daerah Kabupaten Tangerang mengarahkan kampung ini sebagai Kampung Wisata Ziarah, namun belum memiliki perencanaan yang matang. Oleh karena itu, kegiatan KKL dan PKM Program Studi Arsitektur mencoba untuk merencanakan desain yang difokuskan di sisi sempadan Sungai Cisadane kampung ini, karena sisi inilah di mana kampung ini mudah dikenali dari jalan utama BSD City. Kegiatan ini menghasilkan pradesain wisata hijau dan community center di sempadan sungai yang terkoneksi dengan objek-objek pusaka sejarah yang terdapat di dalam kampung sehingga menjadi kesatuan program kegiatan wisata rohani atau religi.
\end{abstract}

Kata Kunci: lengkong kyai, pusat komunitas, pusaka, arsitektur wisata

How to Cite: Khamdevi, M., Effendi, A.C., Lo,M., Prahasta, M.G.M., Rusli,N.H., \& Liauwnardy,L. (2021). Pra-Desain Wisata Hijau Sempadan Sungai dan Community Center Kampung Lengkong Kyai, Tangerang - Banten. Mitra Mahajana: Jurnal Pengabdian Masyarakat, 2(3), 258-266. doi: https://doi.org/10.37478/mahajana.v2i3.1297

\section{PENDAHULUAN}

Pendiri kampung ini, Raden Arya Wangsakara yang berasal dari Sumedang, yang merupakan pangeran dari Kesultanan Cirebon. Beliau juga adalah salah satu pendiri Kota Tigaraksa dan pahlawan dalam sejarah Kesultanan Banten (Tjandrasasmita, 2009). Kampung ini didirikan pertama kali sebagai tempat pesantrian atau pesantren, yang lama-kelamaan berubah menjadi permukiman. Di dalam permukiman terdapat masjid dan musholla bersejarah (Khamdevi, 2016), pola kampung yang mengikuti arah kiblat (Khamdevi, 2012a dan Khamdevi, 2012b), rumah-rumah tradisional Banten Utara yang bergaya Sontog dan Bapang (Khamdevi, 2013), dan makam-makam bersejarah pendiri dan ulama. Kampung ini sangat potensial sekali menjadi wisata rohani atau religi (Khamdevi, 2012c). Kampung ini juga terkenal sebagai pencetak ulama dan kaligrafer di tingkat nasional.

Semenjak pengambangan BSD City, kampung ini semakin 'dibentengi' oleh temboktembok perumahan formal dan bangunan komersial. Hal ini menyebabkan kondisi fisik dan kualitas permukiman yang semakin menurun. Lalu muncul beberapa institusi pendidikan seperti Nanyang School dan Syafana Islamic School. Di lain sisi, ketika pendirian Kota Tangerang Selatan dan Taman Makam Pahlawan Seribu menjadi bagian kota itu, Kabupaten Tangerang 
menjadi tidak memiliki makam pahlawan. Maka Kabupaten Tangerang menjadikan Makam Arya Wangsakara menjadi makam pahlawan wilayah mereka. Namun sayang, keterlibatan mereka hanya sampai di situ tanpa perencanaan matang untuk konservasi dan wisata Kampung Lengkong Kyai yang sangat dibutuhkan oleh masyarakat setempat. Oleh karena itu Program Studi Arsitektur Universitas Matana yang terdiri dari dosen dan mahasiswa mencoba untuk menjawab permasalahan itu dan memberikan input penyelesaian yang lebih matang berupa Pra-Desain, melalui kegiatan Kuliah dan Kerja Lapangan (KKL) dan Pengabdian Kepada Masyarakat (PKM). Kegiatan difokuskan pada sempadan Sungai Cisadane, di mana sisi ini yang mudah dikenali dari luar kampung dan dari jalan utama BSD City.

\section{METODE PELAKSANAAN}

Sasaran peserta kegiatan PKM ini adalah warga Kampung Lengkong Kyai secara umum. Kegiatan dilaksanakan di Kampung Lengkong Kyai secara berkala bersama warga, tokoh dan pejabat lokal secara luring dan daring. Analisis data-data lapangan menggunakan pendekatan Spirit of Place dari Garnham (1985), yakni aspek-aspek natural, cultural, dan visual, untuk menemukan potensi-potensi kawasan secara komperhensif dan dalam. Tahapan pelaksanaan kegiatan ini adalah sebagai berikut:
1. Survey, Interview, dan FGD (Focus Group Discussion) di Lapangan
2. Analisis Pemetaan Kondisi dan Potensi Eksisting
3. Konsep Rencana Zoning dan Konektivitas
4. Konsep Rencana Sempadan Sungai
5. Evaluasi Awal (FGD)
6. Revisi Konsep dan Pra-Desain
7. Evaluasi Akhir (FGD)
8. Revisi Akhir

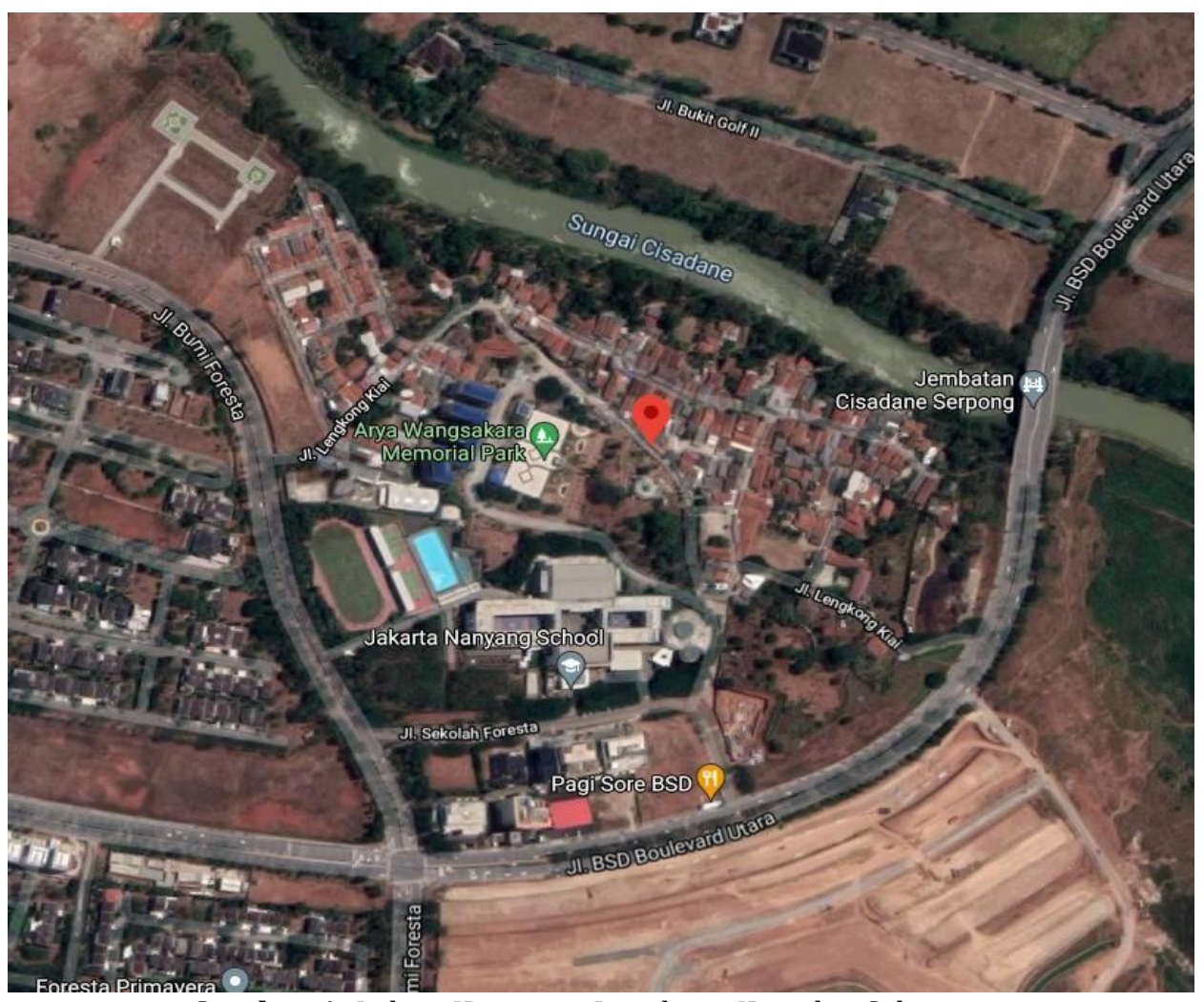

Gambar 1. Lokasi Kampung Lengkong Kyai dan Sekitarnya 


\section{HASIL DAN PEMBAHASAN}

Kegiatan dimulai dengan survey langsung ke lapangan dengan mengadakan pengamatan, dokumentasi, wawancara, dan diskusi. Dari pengamatan awal didapati bahwa lokasi kampung benar-benar terkepung, sehingga tidak terlihat dari luar apakah ada kampung bersejarah atau tidak. Hanya sisi bagian sempadan Sungai Cisadane yang memiliki potensi untuk mudah dikenali dari luar terutama dari jalan raya. Maka diputuskan kegiatan fokus pada tapak ini tanpa melupakan konektivitasnya dengan potensi-potensi yang ada di dalam kampung.

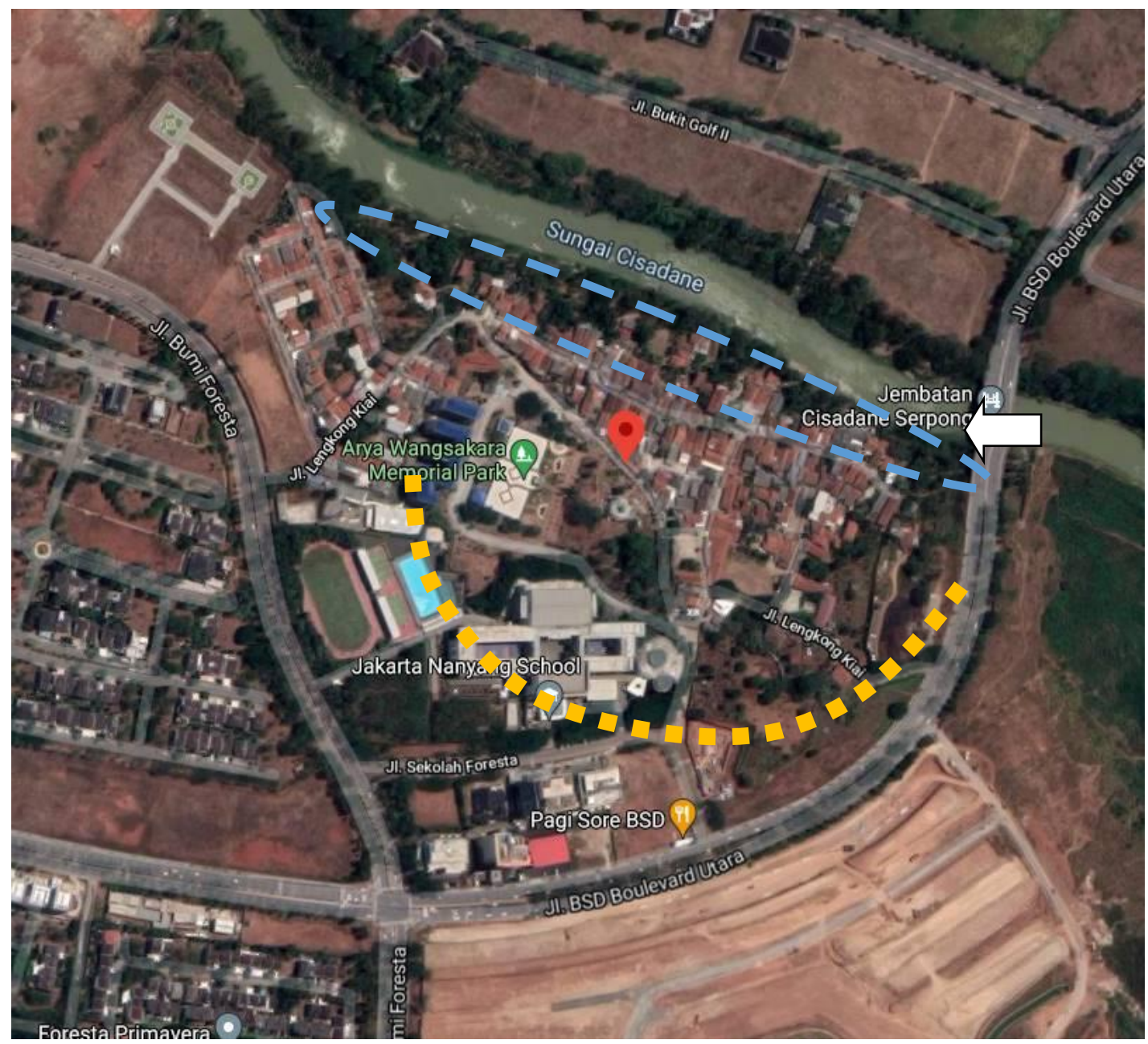

Gambar 2. Lokasi Fokus Kegiatan Pra-Desain

Data-data yang sudah dikumpulkan dari lapangan lalu dianalisis untuk memberikan gambaran utuh mengenai kondisi dan potensi Kampung Lengkong Kyai. Dari analisis ini ditemukan beberapa potensi, yang dibagi sebagai berikut:

1. Potensi Alam: sungai, lahan basah, kontur tanah, dan vegetasi pepohonan

2. Potensi Budaya: sejarah (masjid dan musholla bersejarah, rumah tradisional bersejarah, makam bersejarah dan peziarahan), budaya pesantrian (pesantren) dan kaligrafi, dan kegiatan berkebun

3. Potensi Visual: sungai, vegetasi pepohonan, dan bangunan-bangunan bersejarah 

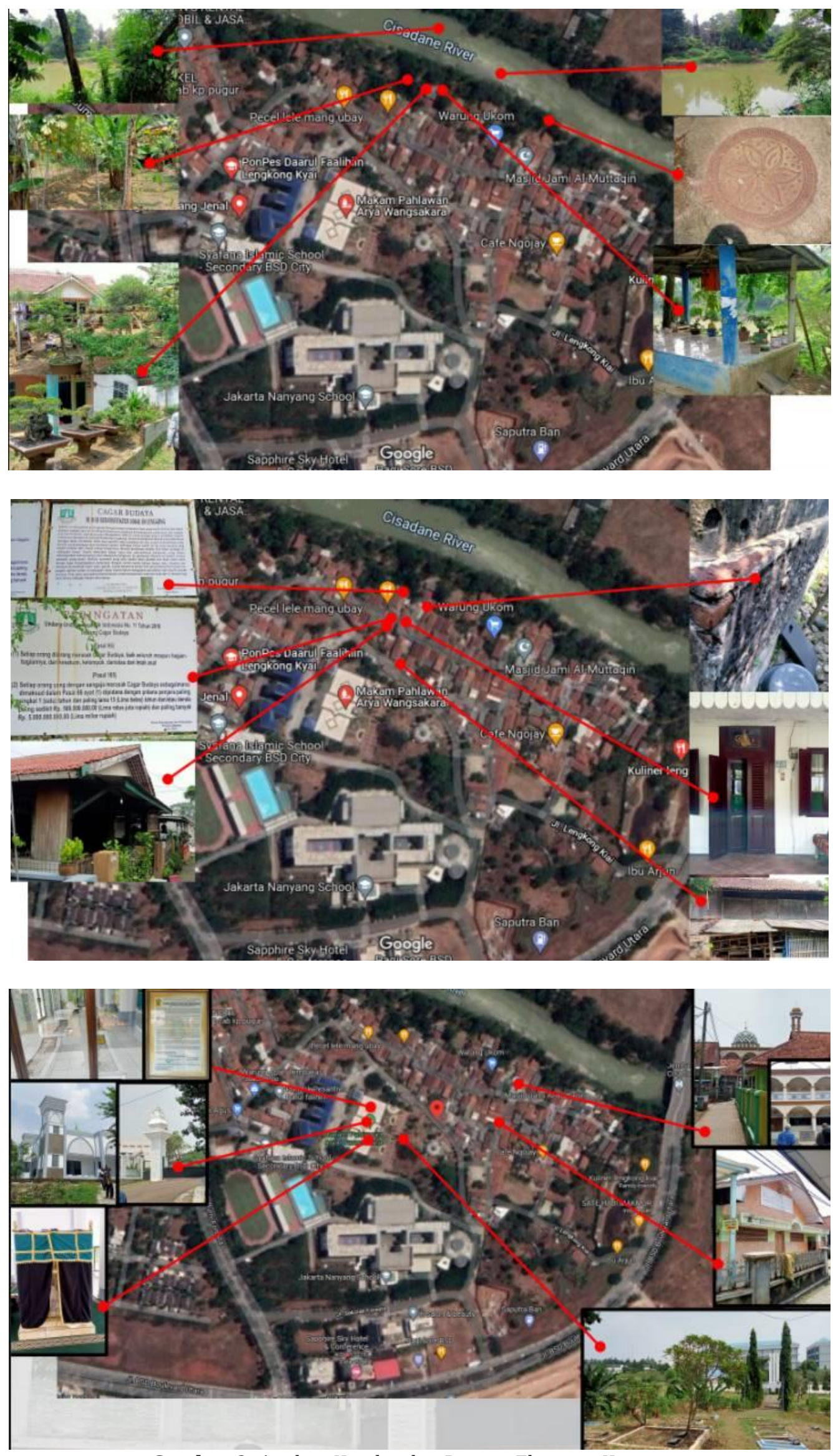

Gambar 3. Analisis Kondisi dan Potensi Eksisting Kampung

261 | PRA-DESAIN WISATA HIJAU SEMPADAN SUNGAI ... KAMPUNG LENGKONG KYAI, TANGERANG - BANTEN 
Setelah mendapatkan gambaran dari analisis data-data lapangan, selanjutnya dilakukanlah perumusan konsep rencana zoning dan konektivitas antar tapak sempadan sungai dengan objek-objek yang ada di dalam kampung untuk membentuk sebuah kegiatan wisata rohani atau religi yang menyatu. Dalam konsep ini direncanakan mulai dari akses utama masuk ke kawasan dan sirkulasi kegiatan-kegiatan. Tapak sempadan sungai memungkinkan untuk dikembangkan adalah 15 meter bibir sungai yang merupakan lahan untuk area hijau dan fasilitas publik yang ditetapkan oleh pemerintah daerah Kabupaten Tangerang.

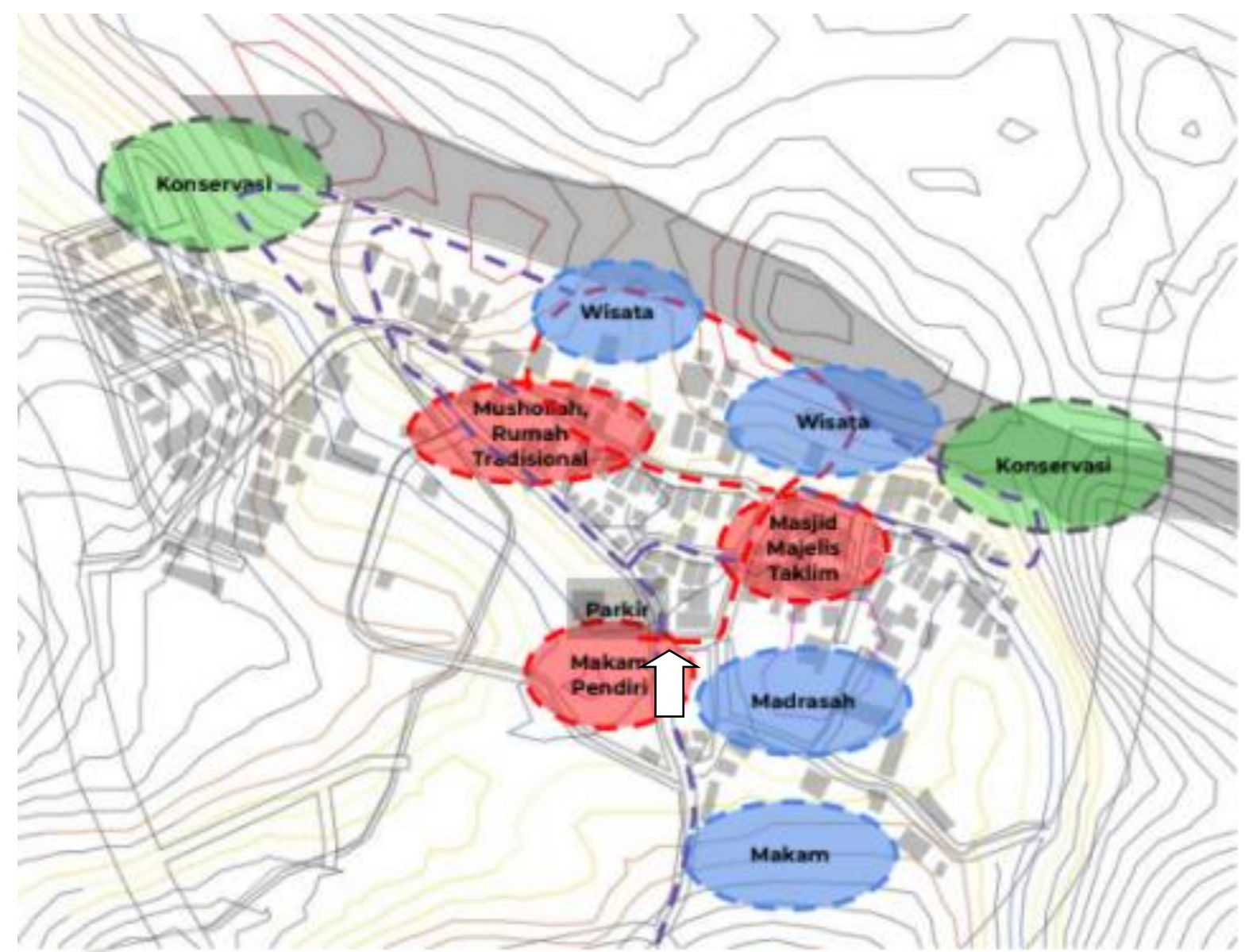

Gambar 4. Konsep Rencana Zoning dan Konektivitas Kegiatan Wisata Rohani atau Religi dan pembagian Zona Tapak Pengembangan Tapak Sempadan Sungai

Setelah itu, dilakukan perumusan konsep tapak sempadan sungai yang akan direncanakan dan dikembangkan. Konsep utama dari tapak sempadan sungai ini adalah "Wisata Pesantren Lengkong Hejo" dengan pendekatan revitalisai kawasan, di mana didalamnya akan ada kegiatankegiatan wisata pesantren kilat, wisata perkebunan dan belanja tanaman hidroponik (aeroponik dan aquaponik), penghijauan dan konservasi lahan basah sempadan sungai, pengolahan limbah air kotor, homestay dan camping atau glamping, jogging dan cycle track, dermaga, dan wisata rakit.

Konsep revitalisasi sungai menggunakan pendekatan hibrid anatara konservasi lahan basah dan fill tanggul bronjong batu yang didesain seperti lengkungan khat naskhi kaligrafi dengan prinsip desain lansekap yang dijadikan sebagai pedoman desain. Hal ini untuk menghindari betonisasi tapi mendorong naturalisasi sempadan sungai. Selain itu tapak ini juga direncanakan untuk kegiatan pengolahan air kotor menjadi air bersih sebelum disimpan ke tanah dengan sumur resapan dan dibuang ke sungai supaya sungai tidak tercemar, serta kegiatan manajemen banjir. Rencana tapak pengembangan dibagi menjadi dua zona wisata dengan tema yang sama dan dua zona konservasi alam. 


\section{KONSEP ZONA PINGGIR SUNGAI: WISATA PESANTREN LENGKONG HEJO PENDEKATAN: Revitalisasi}

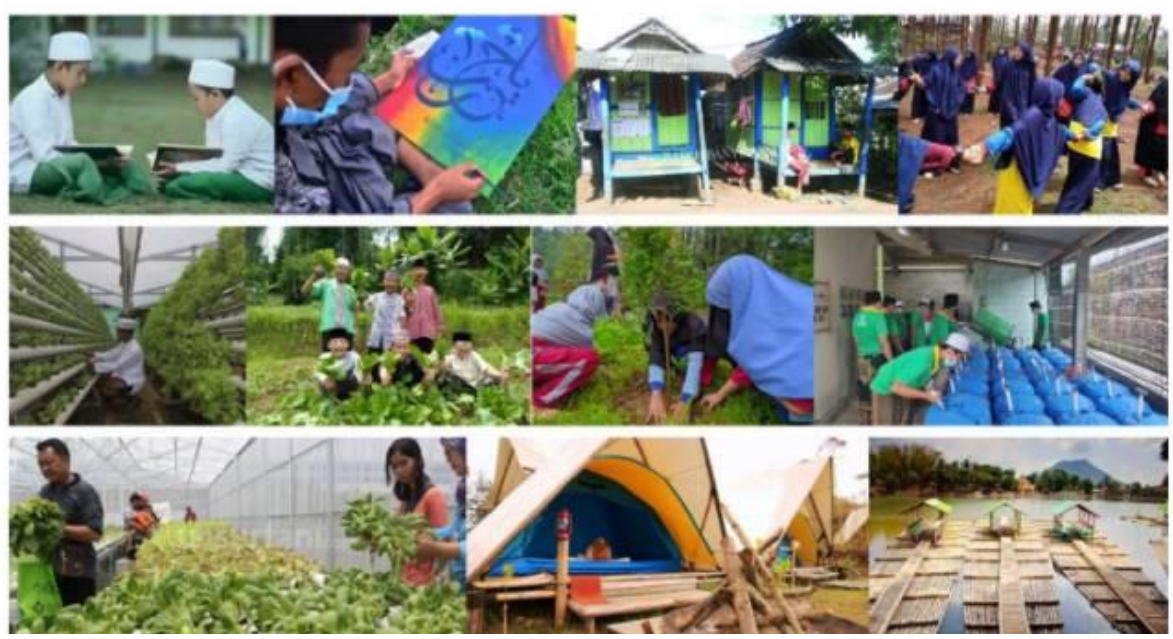

KONSEP TEKNOLOGI PINGGIR SUNGAI: Konservasi Lahan Basah + Fill + Tanggul Bronjong

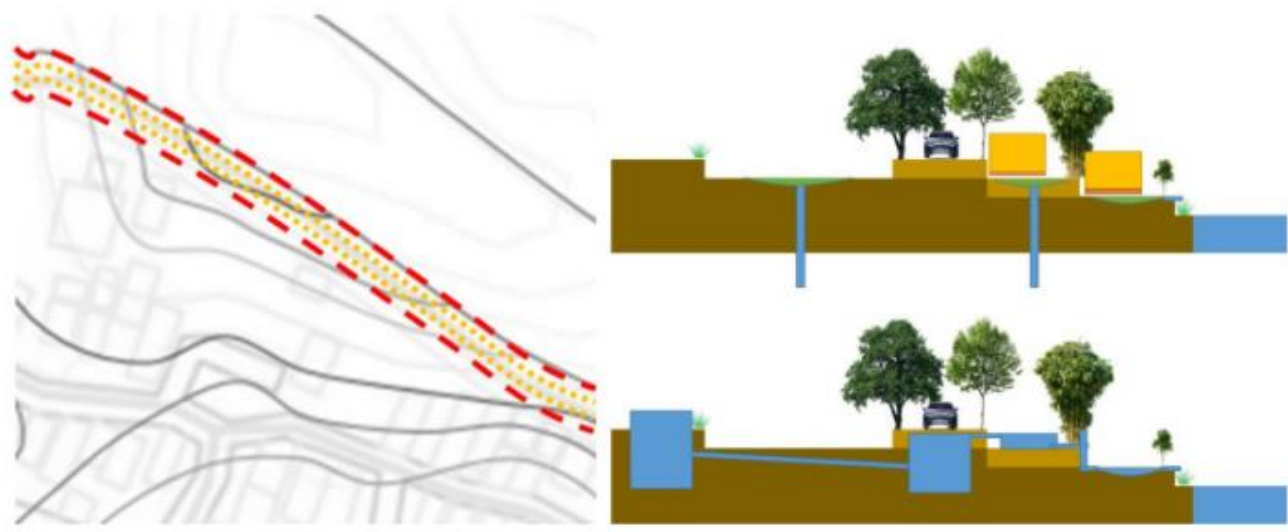

KONSEP DESAIN KONTUR: Khat Naskhi

$$
\begin{aligned}
& \text { نَ }
\end{aligned}
$$

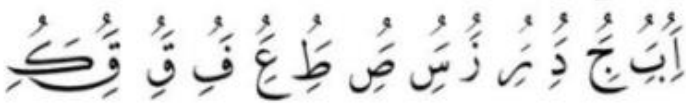

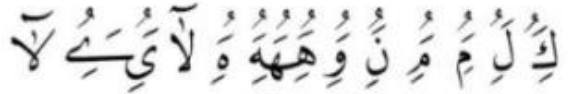

$$
\begin{aligned}
& \text { بـ }
\end{aligned}
$$

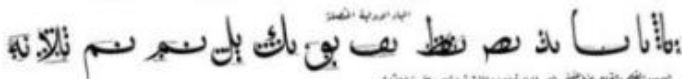




\section{PRINSIP WATER TREATMENT DAN FLOOD MANAGEMENT}

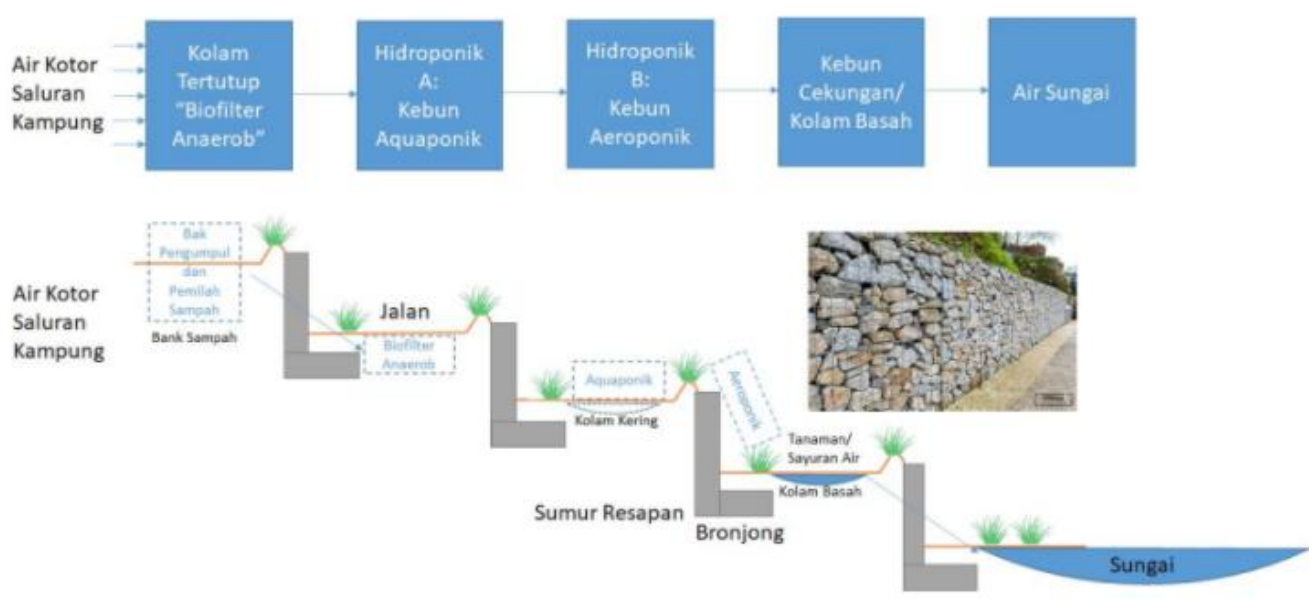

Gambar 5. Konsep Rencana Utama Tapak Sempadan Sungai beserta Pedoman Desainnya

Lalu dipilihlah zona wisata 1, sebagai proyek tahap pertama yang akan digarap pertama kali Pra-Desainnya. Kegiatan di dalamnya terdapat homestay dan camping atau glamping, perkebunan aquaponik, perkebunan aeroponik, perkebunan lahan basah, perkebunan lahan kering, jalan inspeksi, pengolahan air kotor, pengolahan sampah, pusat komunitas, dan dermaga. Letak pusat komunitas dan dermaga diarahkan mengikuti sumbu atau aksis dan simetri refleksi (pencerminan) dari masjid bersejarah. Desain pusat komunitas diarahkan mengikuti desain lama masjid bersejarah dengan penyesuaian bahan berupa kayu dan bambu. Sedangkan desain homestay diarahkan mengikuti desain pondok-pondok santri dan gaya rumah tradisionalnya (Bapang dan Sontog).

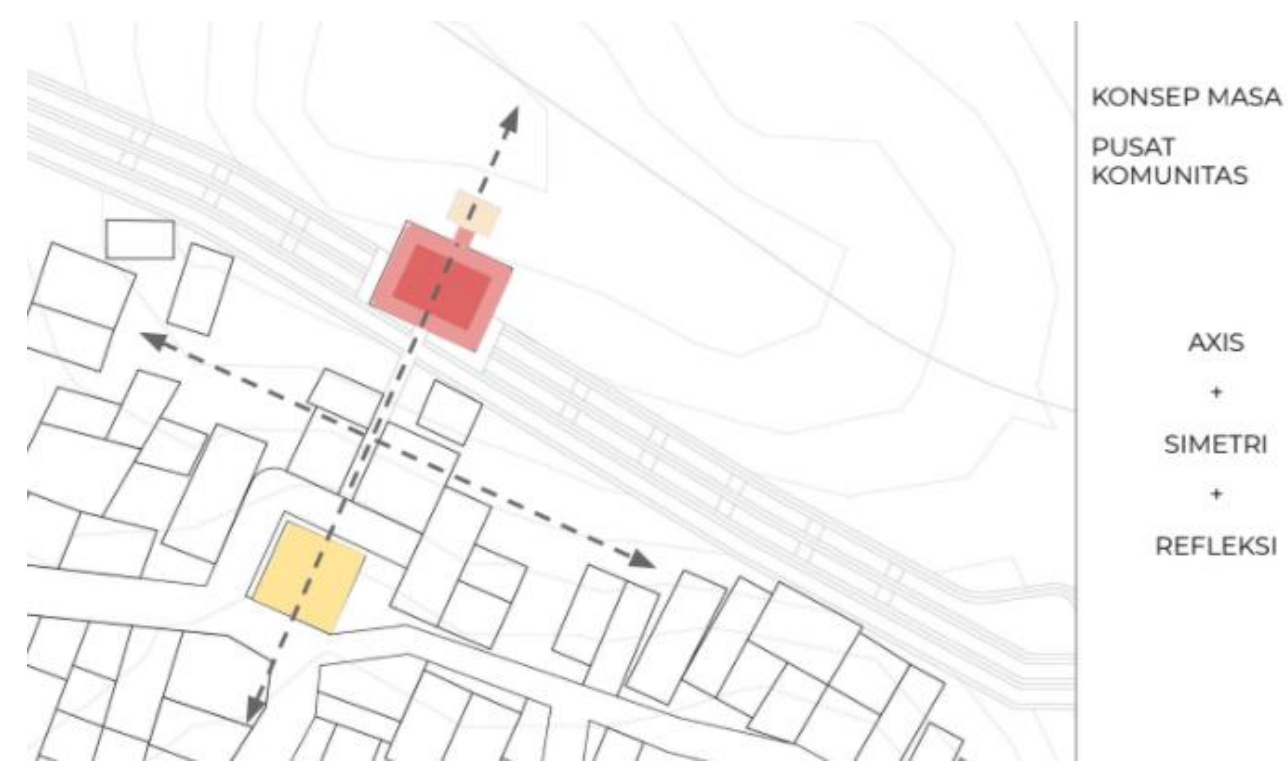



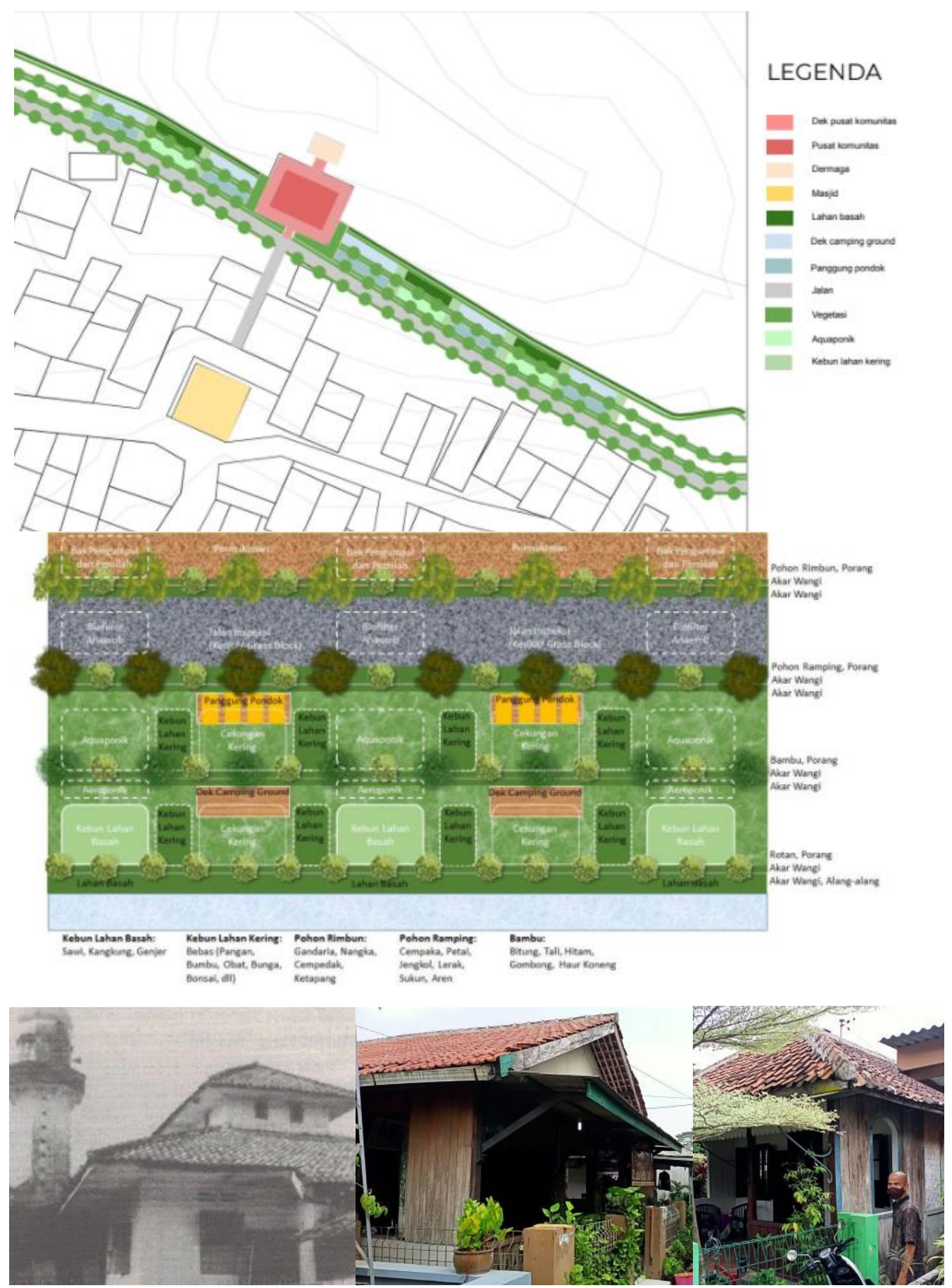

Gambar 6. Pra-Desain Zona Wisata 1 dan Pedoman Desain Bangunan

\section{SIMPULAN DAN TINDAK LANJUT}

Hasil kegiatan KKL dan PKM menghasilkan konsep kawasan yang lebih jelas dan terkoneksi dengan baik, panduan desain kawasan, pra-desain dan panduan desain bangunan untuk zona wisata 1 . Diharapkan dari pengembangan zona tahap 1 ini menjadi stimulasi bagi tahap berikutnya. Sehingga keberadaan kampung ini dapat dikenali dari luar dan mengundang banyak pengunjung untuk melakukan aktifitas wisata yang disediakan atau hanya sekedar menikmati pemandangan dan berolah raga. Tentu saja sasaran pengunjung yang utama adalah para penghuni perumahan formal sekitar dan masyarakat yang lebih luas. Dengan begitu kampung ini bisa terintegrasi dengan fungsi-fungsi yang ada disekitarnya terutama dengan BSD, 
bahkan menjadi ruang terbuka publik dan landmark kawasan BSD. Desain yang lebih detail akan dikerjakan pada KKL dan PKM pada kesempatan berikutnya.

\section{DAFTAR PUSTAKA}

Garnham, H. L. (1985). Maintaining The Spirit of Place: A Process for The Preservation of Town Character. Arizona: PDA Publishers Corp.

Khamdevi, Muhammar (2012a). Kajian Pola Permukiman Khas Kampung Lengkong Ulama, Serpong, Banten. Dimensi: Journal of Architecture and Built Environment, Vol. 39 (1), 3136. https://doi.org/10.9744/dimensi.39.1.31-36

Khamdevi, Muhammar (2012b). Pola Kampung Lengkong Ulama: Kekhasan Yang Sudah Lama Ingin Didengar. Proceeding in Seminar Nasional Dies ke-45 Universitas Kristen Petra, 371379.

Khamdevi, Muhammar (2012c). Religious Tourism Kampong: Integration of Historical Kampong Lengkong Ulama to the Modern City Serpong? Proceeding in 2nd ICSBE Yogyakarta, 333340.

Khamdevi, Muhammar (2013). Karakteristik Rumah Tradisional Di Kampung Bersejarah Lengkong Ulama, Kabupaten Tangerang. Vitruvian Vol. 3 (1), 50-63.

Khamdevi, Muhammar (2016). Evolusi Arsitektur Masjid Raden Arya Wangsakara Kampung Lengkong Kyai, Tangerang. Islamia Vol. 10 (2), 112-117.

Tjandrasasmita, U. (2009). Arkeologi Islam Nusantara. Jakarta: Kepustakaan Populer Gramedia. 